Revista Brasileira de Farmacognosia Brazilian Journal of Pharmacognosy 21(4): 608-614, Jul./Aug. 2011

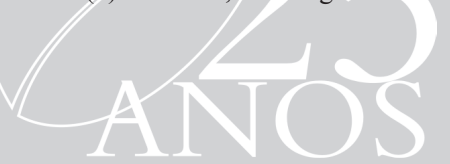

Article

Received 28 Jul 2010

Accepted 16 Dec 2010

Available online 3 Jun 2011

Keywords:

antiherpes

marine organisms

marine sponges

octocoral species

screening

ISSN 0102-695X

doi: $10.1590 /$ S0102-695X2011005000094

\section{Antiherpes screening of marine organisms from Colombian Caribbean Sea}

\author{
Izabella T. Silva, ${ }^{1}$ Thiago Caon, ${ }^{1}$ Débora D. Lückemeyer, ${ }^{1}$ Freddy \\ A. Ramos, ${ }^{2}$ Edisson Tello, ${ }^{2}$ Catalina Arévalo-Ferro, ${ }^{3}$ Eloir $P$. \\ Schenkel, ${ }^{4}$ Carmenza Duque, ${ }^{2}$ Cláudia M. O. Simões ${ }^{* 1}$
}

\author{
${ }^{1}$ Laboratório de Virologia Aplicada, Departamento de Ciências Farmacêuticas, \\ Universidade Federal de Santa Catarina, Brazil, \\ ${ }^{2}$ Departamento de Química, Universidad Nacional de Colombia, Colombia, \\ ${ }^{3}$ Departamento de Biología, Universidad Nacional de Colombia, Colombia, \\ ${ }^{4}$ Departamento de Ciências Farmacêuticas, Universidade Federal de Santa \\ Catarina, Brazil.
}

\begin{abstract}
The exploration of marine environment represents a promising strategy in the search for new active antiviral compounds. The isolation and characterization of the nucleosides spongothymidine and spongouridine from the sponge Cryptotethia crypta used as models for the synthesis of ara-A (vidarabine), that has been used therapeutically against herpetic encephalitis, was the most important contribution since the late 1970s. This paper describes the in vitro antiviral evaluation of 26 organic extracts obtained from eleven octocoral species and fifteen marine sponges. Cytotoxicity was evaluated on Vero cells by MTT assay and the antiviral activity was tested against Herpes Simplex Virus type 1 (HSV-1, KOS strain) by plaque number reduction assay. Results were expressed as $50 \%$ cytotoxic (CC50) and 50\% inhibitory (IC50) concentrations, respectively, in order to calculate the selectivity index ( $\mathrm{SI}=$ CC50/IC50) of each extract. Among the tested marine octocoral species, only three extracts showed antiviral activity, but with low selectivity indices $(\leq 3.0)$. Among the tested marine sponges, eight extracts showed SI values higher than 2.0, and three can be considered promising (Aka cachacrouense, Niphates erecta and Dragmacidon reticulatum) with SI values of 5.0, 8.0 and 11.7, respectively, meriting complementary studies in order to identify the bioactive components of these sponge extracts, which are in course now.
\end{abstract}

\section{Introduction}

Herpes Simplex Virus types 1 and 2 (HSV-1 and HSV-2) are a worldwide occurring human pathogens. There is an urgent need to discover and develop new alternative agents for the management of HSV infection. They are frequently responsible for infections on skin and mucosa of different locations including oral and genital regions. Although infections are often subclinical, HSV can cause mild to severe diseases, especially in neonates and immunocompromised patients. Both types 1 and 2 were the first human herpesviruses to be discovered and are among the most intensively investigated due to their ability to cause a variety of infections, the capacity to remain latent in their host for life, and the possibility to reactivate, causing lesions at or near the site of initial infection. (Roizman et al., 2007).

Currently, there is no cure for the chronic infection, and prolonged therapy with the available antiherpes drugs has resulted in some undesirable effects and induced the emergence of drug-resistant virus strains. Moreover, HSV has been described as a risk factor for HIV infection. This scenario has triggered the search for new antiherpetic agents, especially those with different mechanism of action from that of acyclovir (Van de Perre et al., 2008).

Although the diversity of life in the terrestrial environment is extraordinary, the greatest biodiversity is in the world's oceans, with 34 of the 36 phyla of all globe, approximately 300,000 described species of plants and animals, such as sponges, corals, tunicates, shellfish, bacteria, seaweeds, which represent only a small percentage of the total number of species have yet to be discovered. Marine organisms are increasingly being examined as possible sources of unusual bioactive compounds, therefore the marine environment represents a treasure of useful products awaiting discovery for the treatment of infectious diseases. Ecological pressures, including competition for space, the fouling of the surface, predation, and successfully reproducing have 
led to the evolution of unique secondary metabolites with various biological activities. The importance that these secondary metabolites play in the control of infectious and parasitic organisms was for many years largely overlooked (Da Silva et al., 2006; Laport et al., 2009; Yasuhara-Bell \& Lu, 2010).

Viruses have remained resistant to treatment or prophylaxis longer than any other infectious organism. The search for viral chemotherapeutic agents from marine sources has yielded several promising therapeutic leads reported to display notable antiviral activity. Perhaps the most important antiviral lead of marine origin reported thus far is the nucleoside ara-A. Ara-A (vidarabine) is a semisynthetic compound based on the arabinosyl nucleosides isolated from the sponge Cryptotethia crypta that has been used therapeutically against herpetic encephalitis since the late 1970s. Other examples of drugs obtained from semisynthetic modifications of these nucleosides are ara-C (cytarabine), acyclovir and azidothymidine (zidovudine), which are nowadays in clinical use (Donia \& Hamann, 2003; Molinski et al., 2009; Yasuhara-Bell \& Lu, 2010).

In this study, was evaluated the inhibitory activity against Herpes Simplex Virus type 1 (KOS, strain) of 26 organic extracts $\left(\mathrm{CH}_{2} \mathrm{Cl}_{2}-\mathrm{MeOH} 1: 1\right)$ obtained from eleven octocoral species and fifteen marine sponges.

\section{Materials and Methods}

\section{Collection of marine organism}

The marine invertebrates (33) were collected in different locations at the Santa Marta bay $\left(11^{\circ} 15^{\prime} 01^{\prime \prime}\right.$ $\mathrm{N}$ and 74 $13^{\prime} 50^{\prime \prime} \mathrm{W}$, approximately) and at the Rosario islands (40 $\mathrm{km}$ south west from Cartagena Bay $\left(10^{\circ} 10^{\prime} 27^{\prime \prime} \mathrm{N}\right.$ and $75^{\circ} 48^{\prime} 40^{\prime \prime} \mathrm{W}$, approximately), by means of scuba dive, between September 2005 and March 2006. The samples were identified by Dr. Sven Zea and Dr. Mónica Puyana. Vouchers of each one of the studied species were deposited at the Instituto de Ciencias Naturales-Universidad Nacional de Colombia and at the Instituto de Investigaciones Marinas y Costeras "José Benito Vives De Andréis" Invemar Collections. General information about these marine organisms is shown in Table 1.

\section{Extract preparation}

Organic extracts of the tested marine organisms were prepared according to standard procedures (Tello et al., 2009). Briefly, once the organisms were collected, and rinsed with sterile sea water to remove associated debris, they were frozen until extraction. The samples were cut into small pieces and extracted by maceration in $\mathrm{CH}_{2} \mathrm{Cl}_{2}-\mathrm{MeOH}(1: 1)$ for $24 \mathrm{~h}$, three times. The extract obtained after filtration was then concentrated to dryness under vacuum at $40{ }^{\circ} \mathrm{C}$, and stored at $4{ }^{\circ} \mathrm{C}$ before use. All extracts were dissolved in DMSO 1\% (Merck) and culture medium to a final concentration of $1000 \mu \mathrm{g} / \mathrm{mL}$, aseptically filtered (Millipore $0.22 \mu \mathrm{m}$ ), and stored at -20 ${ }^{\circ} \mathrm{C}$ until tested.

\section{Virus and cell line}

Vero cells (ATCC CCL 81, Rockville, MD, USA) were grown in Eagle's Minimum Essential Medium (MEM; Cultilab, Brazil) and supplemented with 10\% fetal bovine serum (FBS; Gibco, Brazil), penicillin G (100 U/ $\mathrm{mL})$, streptomycin $(100 \mu \mathrm{g} / \mathrm{mL})$ and amphotericin B (25 $\mu \mathrm{g} / \mathrm{mL}$, Cultilab). The cells were maintained at $37{ }^{\circ} \mathrm{C}$ in a humidified atmosphere of $5 \% \mathrm{CO}_{2}$ in air. The Herpes Simplex Virus type 1 (HSV-1, KOS strain) (Faculty of Pharmacy, University of Rennes, France) was propagated in Vero cells, titrated on the basis of plaque forming units (PFU) count by plaque assay as previously described (Burleson et al., 1992) and stored at $-80{ }^{\circ} \mathrm{C}$ until the experiments.

\section{Evaluation of cytotoxicity}

It was performed by MTT [3-(4,5dimethylthiazol-2,5-diphenyl tetrazolium bromide] assay, with minor modifications (Mosmann, 1983). To assess the cytotoxic effects of the samples on uninfected Vero cells $\left(2.5 \times 10^{4}\right.$ cells per well) seeded onto 96-well culture plates, $200 \mu \mathrm{L}$ of their dilutions ranging from 0 to $1000 \mu \mathrm{g} / \mathrm{mL}$ (ratio $1: 2$ ) were added to confluent cell monolayers. As cell controls, only $200 \mu \mathrm{L}$ of MEM were added to the cells. After $72 \mathrm{~h}$ at $37^{\circ} \mathrm{C}$, the medium was removed and $50 \mu \mathrm{L}$ of MTT solution prepared in MEM ( $1 \mathrm{mg} / \mathrm{mL}$; Sigma) were added to each well and the plates incubated for $4 \mathrm{~h}$. The MTT solution was removed, $100 \mu \mathrm{L}$ of DMSO (Nuclear, Brazil) were added to each well to dissolve formazan crystals, and the plates have been gently shaken, whereby crystals were completely dissolved. The absorbances were read on a multiwell

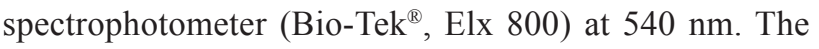
$50 \%$ cytotoxic concentration (CC50) was defined as the concentration of the extracts that reduced cell viability by $50 \%$ when compared to untreated controls.

\section{Viral plaque formation number reduction assay}

This assay followed the procedures previously described (Silva et al., 2010b), with minor modifications. Vero cells $\left(2.5 \times 10^{5}\right.$ cells per well $)$ were seeded onto 24-well culture plates, and after $24 \mathrm{~h}$, the cells were infected with 100 PFU of HSV-1. After $1 \mathrm{~h}$ adsorption at $37{ }^{\circ} \mathrm{C}$, the plates were washed and overlaid with MEM plus $1.5 \%$ carboxymethylcellulose (CMC, Sigma) 
Table 1. Organic extracts of marine organisms from Colombian Caribbean coast and their classes of compounds reported in the literature.

\begin{tabular}{|c|c|c|c|c|c|c|}
\hline Species & $\begin{array}{l}\text { Yield } \\
(\%)\end{array}$ & Collection Number & Family & $\begin{array}{l}\text { Geographic } \\
\text { origin }\end{array}$ & $\begin{array}{l}\text { Classes of } \\
\text { compounds }\end{array}$ & Reference \\
\hline Eunicea laciniata & $5.4 \%$ & ICN-MHN-CR-106 & Plexauridae & Santa Marta & $\begin{array}{l}\text { Pregnane glycosides } \\
\text { Dolabellanes }\end{array}$ & $\begin{array}{l}\text { (Berrue \& Kerr, 2009) } \\
\text { (Rodriguez et al., 1995) }\end{array}$ \\
\hline Eunicea knigthi & $11.6 \%$ & ICN-MHN-CO-0106 & Plexauridae & Santa Marta & Cembranolides & (Tello et al., 2009) \\
\hline Eunicea succinea & $7.4 \%$ & & & & & (Berrue \& Kerr, 2009) \\
\hline $\begin{array}{l}\text { Eunicea succinea } \\
\text { (STA2) }\end{array}$ & $7.4 \%$ & ICN-MHN-PO 0251 & Plexauridae & Santa Marta & $\begin{array}{c}\text { Diterpenes } \\
\text { Pregnane glycosides }\end{array}$ & $\begin{array}{l}\text { (Rodriguez et al., 1995) } \\
\text { (Silva et al., 2010a) }\end{array}$ \\
\hline $\begin{array}{l}\text { Eunicea succinea } \\
\text { (STA 3) }\end{array}$ & $7.4 \%$ & & & & & \\
\hline Eunicea fusca & $10.0 \%$ & ICN-MHN-PO 0252 & Plexauridae & Santa Marta & $\begin{array}{l}\text { Diterpenes and } \\
\text { sesquiterpenes }\end{array}$ & $\begin{array}{l}\text { (Gopichand \& Schmitz, 1978) } \\
\text { (Shin \& Fenical, 1991) }\end{array}$ \\
\hline Eunicea sp2 & $4.0 \%$ & ICN-MHN-PO 0253 & Plexauridae & Santa Marta & Diterpenes & $\begin{array}{l}\text { (Berrue \& Kerr, 2009) } \\
\text { (Rodriguez et al., 1995) }\end{array}$ \\
\hline $\begin{array}{l}\text { Pseudopterogorgia } \\
\text { elisabethae }\end{array}$ & $8.3 \%$ & $\begin{array}{l}\text { INV-CNI-1612 } \\
\text { INV-CNI-1613 } \\
\text { INV-CNI-1614 }\end{array}$ & Gorgoniidae & $\begin{array}{l}\text { Providencia and } \\
\text { San Andres }\end{array}$ & $\begin{array}{l}\text { Pseudopterosins } \\
\text { Secopseudopterosins } \\
\text { Amphilectanes }\end{array}$ & $\begin{array}{l}\text { (Berrue \& Kerr, 2009) } \\
\text { (Duque et al., 2004) } \\
\text { (Duque et al., 2006) }\end{array}$ \\
\hline Muriceopsis sp. & $6.2 \%$ & ICN-MHN-PO 0254 & Plexauridae & Santa Marta & $\begin{array}{l}\text { 4-methylsterols from } \\
\text { symbionts }\end{array}$ & (Kokke et al., 1982) \\
\hline $\begin{array}{l}\text { Palythoa } \\
\text { caribaeorum }\end{array}$ & $1.8 \%$ & ICN-MHN-PO 0255 & Zoanthidae & Santa Marta & $\begin{array}{l}\text { Palythoxin, sterols } \\
\text { and bromine fatty } \\
\text { acids }\end{array}$ & $\begin{array}{c}\text { (Kelecom \& Sole-Cava, 1982) } \\
\text { (Carballeira \& Reyes, 1995) }\end{array}$ \\
\hline Niphates erecta & $2.8 \%$ & INV-POR-138 & Niphatidae & Santa Marta & Glycoproteins & (O'Keefe et al., 1997) \\
\hline Niphates digitalis & $3.1 \%$ & INV-POR-161 & Niphatidae & Santa Marta & $\begin{array}{l}\text { No data but its } \\
\text { extracts show } \\
\text { antibacterial and } \\
\text { ichthyotoxic } \\
\text { properties }\end{array}$ & (Lindquist \& Hay, 1996) \\
\hline $\begin{array}{l}\text { Desmapsamma } \\
\text { anchorata }\end{array}$ & $3.2 \%$ & INV-POR-887 & Desmacididae & Santa Marta & $\begin{array}{c}\text { Lectins, 5-alkyl- } \\
\text { pyrrole-2- } \\
\text { carboxaldehydes and } \\
\text { fatty acids }\end{array}$ & $\begin{array}{c}\text { (Atta et al., 1990) } \\
\text { (Compagnone et al., 1999) } \\
\text { (Carballeira \& Shalabi, 1994) }\end{array}$ \\
\hline $\begin{array}{l}\text { Spirastrella } \\
\text { coccínea }\end{array}$ & $2.9 \%$ & INV-POR 1150 & Spirastrellidae & Santa Marta & $\begin{array}{l}\text { Macrolide } \\
\text { poliketides }\end{array}$ & (Williams et al., 2007) \\
\hline Agelas tubulata & $3.0 \%$ & INV-MHN(Po)-154 & Agelasidae & Santa Marta & $\begin{array}{c}\text { Terpenoids, } \\
\text { pyrrol and } \\
\text { 2-aminoimidazole } \\
\text { alkaloids, and } \\
\text { halogenated } \\
\text { compounds }\end{array}$ & $\begin{array}{l}\text { (Araki et al., 2009) } \\
\text { (Gordaliza, 2009) }\end{array}$ \\
\hline Cliona delitrix & $2.4 \%$ & INV-MHN(Po)-189 & Clionaidae & San Andres & & \\
\hline Cliona tenuis & $5.6 \%$ & INV-POR-669 & Clionaidae & $\begin{array}{l}\text { Islas del } \\
\text { Rosario }\end{array}$ & Fatty acids, Sterols, & $\begin{array}{l}\text { (Carballeira et al., 1989) } \\
\text { (Fattorusso et al., 2004) }\end{array}$ \\
\hline Cliona varians & $4.4 \%$ & INV-POR-339 & Clionaidae & Santa Marta & $\begin{array}{l}\text { Peptide alkaloids, } \\
\text { Lectins }\end{array}$ & $\begin{array}{l}\text { (Palermo et al., 1998) } \\
\text { (Moura et al., 2006) }\end{array}$ \\
\hline $\begin{array}{l}\text { Aka } \\
\text { cachacrouensis }\end{array}$ & $2.2 \%$ & INV-POR-412 & Clionaidae & Santa Marta & & \\
\hline $\begin{array}{l}\text { Dragmacidon } \\
\text { reticulatum }\end{array}$ & $3.1 \%$ & INV-POR-883 & Axinellidae & Santa Marta & $\begin{array}{l}\text { Phospholipids } \\
\text { Sterols }\end{array}$ & $\begin{array}{l}\text { (Sjöstrand et al., 1981) } \\
\text { (Barnathan et al., 1996) }\end{array}$ \\
\hline $\begin{array}{l}\text { Erythropodium } \\
\text { caribbaeorum }\end{array}$ & $3.2 \%$ & INV-CNI-1193 & Anthothelidae & Santa Marta & Diterpenes & (Berrue \& Kerr, 2009) \\
\hline Biemna cribaría & $0.9 \%$ & INV-POR-890 & Desmacellidae & Santa Marta & - & - \\
\hline $\begin{array}{l}\text { Cinachyrella } \\
\text { kuekenthali }\end{array}$ & $3.7 \%$ & INV-POR-878 & Tetillidae & Santa Marta & $\begin{array}{l}\text { Sterols and Fatty } \\
\text { acids }\end{array}$ & $\begin{array}{l}\text { (Barnathan et al., 1992) } \\
\text { (Barnathan et al., 1993) }\end{array}$ \\
\hline
\end{tabular}


containing or not different concentrations of the extracts. After $72 \mathrm{~h}$, the cells were fixed and stained with naphtol blue-black (Sigma) and viral plaque formation were counted. The 50\% inhibitory concentration (IC50) was defined as the concentration that inhibited $50 \%$ of viral plaque formation when compared to untreated controls. Acyclovir (Sigma $\left.{ }^{\circledR}\right)$ was used as a positive control $(10 \mu \mathrm{g} /$ $\mathrm{mL}$ ), since it completely inhibited the viral replication. Its stock solution was prepared in DMSO (Merck) at the final concentration of $1000 \mu \mathrm{g} / \mathrm{mL}$.

Results were expressed as $50 \%$ cytotoxic (CC50) and $50 \%$ inhibitory (IC50) concentrations, respectively, in order to calculate the selectivity index ( $\mathrm{SI}=\mathrm{CC} 50$ / IC50) of each extract (Cos et al., 2006).

\section{Statistical analysis}

The mean \pm standard deviations are representative of three independent experiments. For the determination of CC50 and IC50 values non-linear regressions of concentration-response curves were used.

\section{Results and Discussion}

Over the past 50 years, marine organisms have provided key structures and compounds that proved their potential for industrial development as cosmetics, nutritional supplements, fine chemicals, agrochemicals and therapeutic agents for a variety of diseases. During the past 30 years, thousands of novel compounds with diverse biological activities ranging from anticancer to antiviral have been isolated from various marine sources (Yasuhara-Bell \& Lu, 2010).

In this study, 26 organic extracts obtained from eleven octocoral species and fifteen marine sponges were investigated for their antiviral activity against Herpes Simplex Virus type 1 (HSV-1, KOS strain). Before the evaluation of the antiviral activity, the cytotoxic effects of the selected samples were investigated on VERO cells by MTT assay. For each tested sample, a CC50 value was calculated. This assay has several advantages: it is easy to perform, the evaluations are objective, it can be automated using a personal computer and the cytotoxicity evaluation can be made in parallel with antiviral activity evaluation (Andrighetti-Frohner et al., 2003; Müller et al., 2007; Takeuchi et al., 1991). The results of the cytotoxicity evaluation and the antiherpes activity of the tested extracts are shown in Tables 2 and 3.

Among the octocoral tested extracts, only Eunicea succinea (STA2), Eunicea fusca and Pseudopterogorgia elisabethae (SAN ANDRES) showed antiviral activity. Their IC50 values ranged from 50 to $62.5 \mu \mathrm{g} / \mathrm{mL}$, and their selectivity index values were 1.2, 2.2 and 3.0, respectively. The extracts of Eunicea species pointed to recognize them as a rich source of cembranoid and fuscoside diterpenes, and some sesquiterpenes (Rodríguez, 1995). Several biological activities as antimicrobial, cytotoxic, and acetyl choline inhibitors were reported for compounds isolated from soft octocorals belonging to this genus (Berrue \& Kerr, 2009). Several cembranolides exhibiting cytotoxic and antibacterial activity have been isolated from $E$. succinea (Rodríguez, 1995). E. fusca contains fuscosides A-D, glycosydicaly bound diterpenes with lobane and eudesmane related diterpene skeleton that presented interesting anti-inflammatory activity (Shin \& Fenical, 1991; Jacobson \& Jacobs, 1992). On the other hand, $P$ elisabethae has been widely studied by the presence of diterpenes, mainly pseudopterosins and related compounds that present proved activity as anti-inflammatory compounds (Correa et al., 2009). In Colombia, two chemotypes with a different and characteristic contents of pseudopterosins and secopseudopterosins has been reported as part of our research (Puyana et al., 2004) as well as several new compounds have been isolated (Duque et al., 2004, Duque et al., 2006).

Table 2. Cytotoxicity and antiherpes activity of octocoral species extracts.

\begin{tabular}{lccc}
\hline \multirow{2}{*}{ Samples } & \multicolumn{3}{c}{ HSV-1 (KOS strain) } \\
\cline { 2 - 4 } & CC50 & IC50 & SI \\
\hline Eunicea laciniata & $44.9 \pm 4.9$ & $\mathrm{NI}$ & - \\
Eunicea flexuosa & $44.1 \pm 0.4$ & $\mathrm{NI}$ & - \\
Eunicea succinea (STA2) & $62.5 \pm 0.1$ & $50.0 \pm 0.1$ & 1.2 \\
Eunicea succinea (STA 3) & $62.5 \pm 0.2$ & $\mathrm{NI}$ & - \\
Eunicea fusca & $137.2 \pm 10.6$ & $62.5 \pm 0.2$ & 2.2 \\
Muriciopsis sp. & $53.1 \pm 0.9$ & $\mathrm{NI}$ & - \\
Pseudopterogorgia elisabethae & $62.5 \pm 0.2$ & $\mathrm{NI}$ & - \\
(Providencia) & & & \\
Pseudopterogorgia elisabethae & $184.5 \pm 3.5$ & $62.5 \pm 0.1$ & 3 \\
(San Andres) & & & \\
Eunicea sp2 & $228.7 \pm 0.3$ & $\mathrm{NI}$ & - \\
Palythoa caribaeorum & \\
& & & \\
CC50: 50\% cytotoxic concen & $500.0 \pm 0.0$ & $\mathrm{NI}$ & \\
\hline
\end{tabular}

CC50: $50 \%$ cytotoxic concentration $(\mu \mathrm{g} / \mathrm{mL})$; IC50: $50 \%$ inhibitory concentration $(\mu \mathrm{g} / \mathrm{mL})$; SI: selectivity index $(=$ CC50/IC50); NI = no inhibitory activity; $a$ : Zooanthid.

The natural products chemistry of tropical marine sponges has been well investigated (Faulkner, 1998), and many sponge secondary metabolites have been isolated and characterized, including some with potent antiviral activity (Waddell \& Pawlik, 2000).

For organic extract from the Niphates erecta, a moderate antiviral activity $(\mathrm{SI}=8)$ was shown (Cos et al., 2006). It has been reported that an anti-human immunodeficiency virus (HIV)-bioassay-guided fractionation of aqueous extracts of this caribbean sponge, led to isolation of a novel anti-HIV protein, named niphatevirin (O'Keefe et al., 1997). Therefore, the antiviral effect observed for Niphates erecta could 
be associated with the presence of this compound (Kleymann, 2005; Kucze et al., 2010).

Dragmacidon reticulatum was the extract that showed higher activity against HSV-1 (SI=11.7). For this genus, the occurrence of fosfolipids (Barnathan et al., 1992) and sterols (Sjöstrand et al., 1981) has been described and related to the antiviral activity detected for this extract (Hudson \& Towers, 1999). For the $A k a$ cachacrouense, a modest activity against the replication of the HSV-1 (SI=5.0) was found. The others organic extracts from marine sponges presented lower anti-HSV-1 activity (SI values ranged between 2.0 and 2.5).

Currently, more than 200 natural products with promising levels of antiviral activity have been isolated from aqueous or organic extracts of marine organisms. Continuous searching for and testing of natural compounds for their antiviral potential will likely lead to the discovery and development of a new generation of antiviral agents that can effectively control viral diseases in humans, as well as in other valuable animal species (Yasuhara-Bell \& Lu, 2010).

Considering the results obtained, it can be stated that the tested extracts protect against viral infection, but the mechanism of their antiviral action and the active substances have not identified yet. Further studies are needed in order to verify which compounds could be responsible for this activity and how they exert their antiviral effects. Studies with these goals are under development in our laboratory.

Table 3. Cytotoxicity and antiherpes activity of marine sponges extracts.

\begin{tabular}{lccc}
\hline \multirow{2}{*}{\multicolumn{1}{c}{ Samples }} & \multicolumn{3}{c}{ HSV-1 (KOS strain) } \\
\cline { 2 - 4 } & CC50 & IC50 & SI \\
\hline Niphates erecta & $500.0 \pm 0.2$ & $62.5 \pm 0.0$ & 8.0 \\
Niphates digitalis & $500.0 \pm 0.0$ & NI & - \\
Desmapsamma anchorata & $296.4 \pm 4.2$ & $150.0 \pm 0.0$ & 2.0 \\
Spirastrella coccinea & $364.6 \pm 0.2$ & $150.0 \pm 0.0$ & 2.5 \\
Agelas conifera & $305.0 \pm 4.0$ & NI & - \\
Cliona delitrix & $500.0 \pm 0.0$ & NI & - \\
Cliona tenuis & $780.0 \pm 2.0$ & $364.0 \pm 14.0$ & 2.1 \\
Cliona varians & $500.0 \pm 0.0$ & $250.0 \pm 0.0$ & 2.0 \\
Aka cachacrouens & $500.0 \pm 0.2$ & $100.5 \pm 18.5$ & 5.0 \\
Dragmacidon reticulatum & $110.5 \pm 1.5$ & $9.5 \pm 0.5$ & 11.7 \\
Erythropodium caribbaeorum & $184.5 \pm 3.5$ & NI & - \\
Biemna cribaria & $376.5 \pm 20.5$ & NI & - \\
Cinachyrella kuekenthali & $760.0 \pm 95.0$ & NI & -
\end{tabular}

CC50: $50 \%$ cytotoxic concentration $(\mu \mathrm{g} / \mathrm{mL})$; IC50: $50 \%$ inhibitory concentration $(\mu \mathrm{g} / \mathrm{mL})$; SI: selectivity index $(=\mathrm{CC} 50 / \mathrm{IC} 50)$; $\mathrm{NI}=$ no inhibitory activity.

\section{Acknowledgements}

This work was conducted as part of a bilateral
(Brazil and Colombia) cooperative project financially supported by CNPq/MCT/Brazil (grant number 490151/2007-8) and COLCIENCIAS/Colombia (3582007). CMO Simões and EP Schenkel are grateful to CNPq for their research fellowships. IT Silva, DD Lückemeyer and $\mathrm{T}$ Caon also acknowledged CAPES/MEC/Brazil and $\mathrm{CNPq}$ for their graduate fellowships.

\section{References}

Andrighetti-Frohner CR, Antonio RV, Creczynski-Pasa TB, Barardi CRM, Simões CMO 2003. Cytotoxicity and potential antiviral evaluation of violacein produced by Chromobacterium violaceum. Mem I Oswaldo Cruz 98: 843-848.

Araki A, Kubota T, Aoyama K, Mikami Y, Fromont J, Kobayashi J 2009. Nagelamides Q and R, novel dimeric bromopyrrole alkaloids from sponges agelas sp. Org Lett 11: 17851788 .

Atta AM, Menezes EP, Peixinho S, Sousa-Atta ML 1990. Isolation of a lectin from the marine sponge Desmapsama anchorata by affinity chromatography on raffinosesepharose 6B. Braz J Med Biol Res 23: 191-194.

Barnathan G, Kornprobst JM, Doumenq P, Miralles J 1996. New unsaturated long-chain fatty acids in the phospholipids from the Axinellida sponges Trikentrion loeve and Pseudaxinella cf. lunaecharta. Lipids 31: 193-200.

Barnathan G, Miralles J, Kornprobst J-M 1993. Sponge fatty acids-4. Co-occurrence of two isoprenoid fatty acids (4,8,12-trimethyltridecanoic and 5,9,13trimethyltetradecanoic) in phospholipids of marine sponges from the genus Cinachrella. Nat Prod Lett 3: $113-118$

Barnathan G, Miralles J, Njinkoue JM, Mangoni A, Fattorusso E, Debitus C, Boury-Esnault N, Kornprobst JM 1992. Sterol composition of three marine sponge species from the genus Cinachyrella. Comp Biochem Physiol B Biochem Mol Biol 103: 1043-1047.

Berrue F, Kerr RG 2009. Diterpenes from gorgonian corals. Nat Prod Rep 26: 681-710.

Burleson FG, Chamberts TM, Wiedbrauk DL 1992. Virology: $a$ laboratory manual. San Diego: Academic Press.

Carballeira NM, Maldonado ME, Rivera E, Porras B 1989. The fatty acid 4,8,12-trimethyltridecanoic as a common constituent of the phospholipids of the sponge families Spirastrellidae and Clionidae. Biochem Syst Ecol 17: 311-314.

Carballeira NM, Reyes M 1995. Identification of a new 6-bromo5,9-eicosadienoic acid from the anemone Condylactis gigantea and the zoanthid Palythoa caribaeorum. J Nat Prod 58: 1689-1694.

Carballeira NM, Shalabi F 1994. Unusual lipids in the Caribbean sponges Amphimedon viridis and Desmapsamma anchorata. J Nat Prod 57: 1152-1159.

Compagnone RS, Oliveri MC, Piña IC, Marques S, Rangel HR, Dagger F, Suárez AI, Gómez M 1999. 5-Alkylpyrrole2-carboxaldehydes from the Caribbean sponges Mycale microsigmatosa and Desmapsamma anchorata. Nat Prod Lett 13: 203-211.

Correa H, Valenzuela AL, Ospina LF, Duque C 2009. Anti- 
inflammatory effects of the gorgonian Pseudopterogorgia elisabethae collected at the islands of Providencia and San Andres (SW Caribbean). J Inflamm 6: 1-10.

Cos P, Vlietinck AJ, Vanden Berghe D, Maes L 2006. Antiinfective potential of natural products: How to develop a stronger in vitro "proof-of-concept". J Ethnopharmacol 106: 290-302.

Da Silva AC, Kratz JM, Farias FM, Henriques AT, Dos Santos J, Leonel RM, Lerner C, Mothes B, Barardi CRM, Simões CMO 2006. In vitro antiviral activity of marine sponges collected of Brazilian coast. Biol Pharm Bull 29: $135-$ 140 .

Donia M, Hamann MT 2003. Marine natural products and their potential applications as anti-infective agents. Lancet Infect Dis 3: 338-348.

Duque C, Puyana M, Castellanos L, Arias A, Correa H, Osorno O, Asai T, Hara N, Fujimoto Y 2006. Further studies on the constituents of the gorgonian octocoral Pseudopterogorgia elisabethae collected in San Andrés and Providencia islands, Colombian Caribbean: isolation of a putative biosynthetic intermediate leading to erogorgiaene. Tetrahedron 62: 4205-4213.

Duque C, Puyana M, Narvaez G, Osorno O, Hara N, Fujimoto Y 2004. Pseudopterosins P-V, new compounds from the gorgonian octocoral Pseudopterogorgia elisabethae from Providencia island, Colombian Caribbean. Tetrahedron 60: 10627-10635.

Fattorusso E, Taglialatela-Scafati O, Petrucci F, Bavestrello G, Calcinai B, Cerrano C, Di Meglio P, Ianaro A 2004. Polychlorinated Androstanes from the burrowing sponge Cliona nigricans. Org Lett 6: 1633-1635.

Faulkner DJ 1998. Marine natural products. Nat Prod Rep 15: 113-158.

Gleibs S, Mebs D, Werding B 1995. Studies on the origin and distribution of palytoxin in a Caribbean coral reef. Toxicon 33: 1531-1537.

Gopichand Y, Schmitz FJ 1978. Marine natural products: Fuscol, a new elemene-type diterpene alcohol from the gorgonian Eunicea fusca. Tetrahedron Lett 19: 3641-3644.

Gordaliza M 2009. Terpenyl-purines from the sea. Marine Drugs 7: 833-849.

Hudson J, Towers GHN 1999. Phytomedicines as antivirals. Drugs of the Future 24: 295-320.

Jacobson PB, Jacobs RS 1992. Fuscoside: an anti-inflammatory marine natural product which selectively inhibits 5-lipoxygenase. Part I: Physiological and biochemical studies in murine inflammatory models 1. J Pharm Exp Ther 262: 866-863.

Kelecom A, Sole-Cava AM 1982. Comparative study of zoanthid sterols the genus Palythoa (hexacorallia, zoanthidea). Comp Biochem Physiol B 72: 677-682.

Kleymann G 2005. Agents and strategies in development for improved management of herpes simplex virus infection and disease. Expert Opin Investig Drugs 14: 135-161.

Kokke W, Bohlin L, Fenical W, Djerassi C 1982. Novel dinoflagellate 4 [alpha]-methylated sterols from four caribbean gorgonians. Phytochemistry 21: 881-887.

Kuczer M, Dziubasik K, Midak-Siewirska A, Zahorska R, Luczak M, Konopińska D 2010. Studies of insect peptides alloferon, any-GS and their analogues. Synthesis and antiherpes activity. J Pept Sci 16: 186-189.
Laport MS, Santos OC, Muricy G 2009. Marine sponges: potential sources of new antimicrobial drugs. Curr Pharm Biotechnol 10: 86-105.

Lindquist N, Hay ME 1996. Palatability and chemical defense of marine invertebrate larvae. Ecol Monogr 66: 431-450.

Molinski TF, Dalisay DS, Lievens SL, Saludes JP 2009. Drug development from marine natural products. Nat Rev Drug Discov 8: 69-85.

Mosmann T 1983. Rapid colorimetric assay for cellular growth and survival: application to proliferation and cytotoxicity assays. J Immunol Methods 65: 55-63.

Moura RM, Queiroz AFS, Fook JMSLL, Dias ASF, Monteiro NKV, Ribeiro JKC, Moura GEDD, Macedo LLP, Santos EA, Sales MP 2006. CvL, a lectin from the marine sponge Cliona varians: Isolation, characterization and its effects on pathogenic bacteria and Leishmania promastigotes. Comp Biochem Phys A 145: 517-523.

Müller VDM, Chávez JH, Reginatto FH, Zucolotto SM, Niero R, Navarro D, Yunes RA, Schenkel EP, Barardi CRM, Zanetti CR, Simões CMO 2007. Evaluation of antiviral activity of South American plant extracts against herpes simplex virus type 1 and rabies virus. Phytother Res 21 : 970-974.

O'Keefe BR, Beutler JA, Cardellina II JH, Gulakowski RJ, Krepps BL, McMahon JB, Sowder II RC, Henderson LE, Pannell LK, Pomponi SA, Boyd MR 1997. Isolation and characterization of niphatevirin, a humanimmunodeficiency-virus-inhibitory glycoprotein from the marine sponge Niphates erecta. Eur J Biochem 245: 47-53.

Palermo JA, Brasco MFR, Cabezas E, Balzaretti V, Seldes AM 1998. Celenamide E, a tripeptide alkaloid from the Patagonian sponge Cliona chilensis. J Nat Prod 61: 488490.

Puyana M, Narvaez G, Paz A, Osorno O, Duque C 2004. Pseudopterosin content variability of the purple sea whip Pseudopterogorgia elisabethae at the islands of San Andres and Providencia (SW Caribbean). J Chem Ecol 30: 1183-1201.

Rodríguez A 1995. The natural products chemistry of West Indian Gorgonian Octocorals. Tetrahedron 51: 4571-4618.

Rodriguez AD, Gonzállez E, Gonzállez C 1995. Additional dolabellane diterpenes from the Caribbean gorgonian octocoral Eunicea laciniata. J Nat Prod 58: 226-232.

Roizman B, Knipe DM, Whitley RJ 2007. Herpes Simplex Viruses. In Knife DM, Howley PM, Griffin D, Lamb R, Martin M, Roizman B, Straus SE (org.) Fields Virology 5. ed. Philadelphia: Lippincott Willians \& Wilkins, p. 2502-2601.

Shin J, Fenical W 1991. Fuscosides A-D: anti-inflammatory diterpenoid glycosides of new structural classes from the caribbean gorgonian Eunicea fusca. J Org Chem 56: 3153-3158.

Silva CTC, Hernández LC, Reyes OEO, Rodríguez FAR, Beltrán CD, Hegedus MP 2010a. Chemical study and antifouling activity of caribbean octocoral Eunicea laciniata. Quim Nova 33: 656-661.

Silva IT, Costa GM, Stoco PH, Schenkel EP, Reginato FH, Simões CMO 2010b. In vitro antiherpes effects of a C-glycosylflavonoid enriched fraction of Cecropia glaziovii Sneth. Lett Appl Microbiol 51: 143-148. 
Sjöstrand U, Kornprobst JM, Djerassi C 1981. Minor and trace sterols from marine invertebrates 29. (22E)ergosta-5,22,25-trien-3[beta]-ol and (22E,24R)-24,26dimethylcholesta-5,22,25(27)-trien-3[beta]-ol. Two new marine sterols from the sponge Pseudaxinella lunacharta. Steroids 38: 355-364.

Takeuchi H, Baba M, Shigeta S 1991. An application of tetrazolium (MTT) colorimetric assay for the screening of anti-herpes simplex virus compounds. $J$ Virol Methods 33: 61-71.

Tello E, Castellanos L, Arevalo-Ferro C, Duque C 2009. Cembranoid diterpenes from the Caribbean sea whip Eunicea knighti. J Nat Prod 72: 1595-1602.

Van de Perre P, Segondy M, Foulongne V, Ouedraogo A, Konate I, Huraux JM, Mayaud P, Nagot N 2008. Herpes simplex virus and HIV-1: deciphering viral synergy. Lancet Infect Dis 8: 490-497.

Waddell B, Pawlik JR 2000. Defenses of Caribbean sponges against invertebrate predators. I. Assays with hermit crabs. Mar Ecol Prog Ser 195: 125-132.

Williams DE, Keyzers RA, Warabi K, Desjardine K, Riffell JL, Roberge M, Andersen RJ 2007. Spirastrellolides C to G: Macrolides obtained from the marine sponge Spirastrella coccinea. J Org Chem 72: 9842-9845.

Yasuhara-Bell J, Lu Y 2010. Marine compounds and their antiviral activities. Antiviral Res 86: 231-240.

\section{*Correspondence}

Cláudia M. O. Simões

Laboratório de Virologia Aplicada, Departamento de Ciências Farmacêuticas, Centro de Ciências da Saúde, Universidade Federal de Santa Catarina

Campus Universitário Trindade, Florianópolis, 88040-900, SC, Brazil

claudias@reitoria.ufsc.br

Tel.: +554837215207

Fax: +554837219258 